\title{
GENETIC RELATIONSHIPS AMONG NORTH-WESTERN EUROPEAN GAMMARIDAE (AMPHIPODA)
}

\author{
BY \\ ARNFINN SKADSHEIM \\ Øye Havbruk A/S, P.O. Box 66, N. 4484 Øyestranda, Norway \\ and
}

HANS REDLEF SIEGISMUND

Zoological Institute, University of Munich, Seidlstrasse 25, D-8 Munich 2, Federal Republic of Germany

\section{INTRODUCTION}

Historically the classification of species in the family Gammaridae sensu Lincoln (1979), whose terminology we have chosen to follow in this paper, has been subjected to many changes. Around 1850 several species were described in the genus Gammarus Fabricius, 1775 (see for example Rathke, 1843; Lilljeborg, 1852, 1855; Sars, 1863) but later, especially in the beginning of the 20th century, most of the descriptions were rejected and/or returned to the three classical species Gammarus pulex (L., 1758), Chaetogammarus marinus (Leach, 1815) and Gammarus locusta (L., 1758). At that time Sexton (1912) initiated rearing and crossing experiments of several Gammarus forms. Her description of Gammarus zaddachi in 1912 was, however, first accepted in the next phase around 1930 to 1950 when most of the present marine and brackish water species were described. Stock (1967) settled the marine species picture in north-western Europe to the present state when he separated the G. locustacomplex into seven species. The controversy about the higher classification in Gammaridae is reflected in Bousfield (1977, 1979a, 1981, 1983) and Karaman \& Barnard (1979); Barnard \& Karaman (1980); Barnard \& Barnard (1983). As appears from this sample of papers, possibly convergent evolution of morphological characters renders classification above the species level very difficult. Lincoln (1979) partly followed Bousfield (1977) and recognized four genera: Gammarus, Chaetogammarus Martynov, 1925, Eulimnogammarus Bazikalova, 1945 and Pectenogammarus Reid, 1940.

The occurrence of species groups in well defined habitats or geographical regions has been used for placing these groups in their own genus. Karaman (1931), for example, introduced Rivulogammarus to separate freshwater and marine species, but Stock (1969a) showed that Rivulogammarus must be rejected 
as a generic name according to the rules of the International Code of Zoological Nomenclature. Comprehensive reviews of the systematics of freshwater Gammarus are presented by Karaman \& Pinkster (1977a, b); Barnard \& Barnard (1983). Sket (1971) proposed Lagunogammarus as a new genus covering the species G. zaddachi, Gammarus salinus Spooner, 1947 and Gammarus oceanicus Segerstråle, 1947 that occur under estuarine conditions plus the arctic species Gammarus wilkitzkii Birula, 1897 and Gammarus setosus Dementieva, 1931, and this genus is now accepted by Bousfield (1979b). Members of Eulimnogammarus were believed to occur only in Lake Baikal and in the Arctic region, until Stock (1969) placed a new species from the inland waters of Spain and two additional species in this genus. Pinkster \& Stock (1970) and Pinkster (1973) placed additional European species in Eulimnogammarus. Pinkster disregarded a possible immigration to Europe from Lake Baikal and suggested that the genus must have been in both areas since the Miocene.

An important morphological trait that has been used for the separation of species into genera is the form of uropod 3. Schellenberg (1937) suggested Marinogammarus as a subgenus for species with a reduced inner ramus of uropod 3. Sexton \& Spooner (1940) raised Marinogammarus to generic rank. Stock (1968), however, pointed out that Marinogammarus was a junior synonym of Chaetogammarus. Many Gammaridae from Eurasia are characterized by a reduced inner ramus in uropod 3 , in combination with simple gills and no projection of the basis of pereopod 7 (Stock, 1971). Stock recognized three major groups based on these traits: the Sarothrogammarus-group, the EchinogammarusChaetogammarus-group and the Eulimnogammarus-group, Karaman (1975) synonymized Chaetogammarus and Pectenogammarus with Echinogammarus and in (Karaman, 1977) he also questioned the separation of Sarothrogammarus from Echinogammarus. Barnard \& Karaman (1980) relied only on uropod 3 as a distinguishing character, and regarded even the Gammarus-Echinogammarus grouping as a temporary classification, but Bousfield (1983) pointed to the high degree of intermediate characters that describe the whole superfamily Gammaroidea, and he regarded the characterization of Barnard \& Karaman (1980) as unrealistically rigid.

Few fossils are available to support the morphological principles for phylogenetic classification (Hessler, 1969), and the oldest Gammarus-like fossil has been dated back only to Upper Eocene (Just, 1974). Bousfield (1979b) suggested that the whole superfamily Gammaroidea could have diversified during the last 50 million years, and in Bousfield (1983) he indicated that Amphipoda may be older than expressed earlier. Barnard \& Barnard (1983) propose an origin even before the breakup of Pangea.

Holmes (1975) used numerical taxonomic techniques to compare morphological measurements of thirteen Gammarus and Marinogammarus species. His analysis mainly confirmed the differences between the two genera. Another taxonomic approach was that of Orian \& Callan (1957) who studied 
chromosome numbers in nine Gammaridae for the degree of polyploidy. They concluded that chromosome investigations did not lend themselves well to taxonomic studies of Gammaridae, since the chromosomes generally are very small and overlap in numbers from species to species.

Roux (1967) performed chromatographic analysis of amino acids of Gammaridae, and several workers in north-western European waters (Nyman \& Westin, 1969; Bulnheim \& Scholl, 1980, 1981; Kolding \& Simonsen, 1983; Siegismund et al., 1985) have studied protein polymorphism by means of enzyme electrophoresis to describe systematic relationships in the family Gammaridae. Bulnheim \& Scholl (1981) and Kolding \& Simonsen (1983) regarded their material as too limited to construct phyletic dendrograms, while this was done when Siegismund et al. (1985) analyzed the protein relationships of eighteen loci between Gammarus duebenii Lilljeborg, 1851, G. zaddachi, G. salinus, $G$. oceanicus, G. locusta and Chaetogammarus marinus. Their results indicated that $C$. marinus was no more differentiated from the five other species, than some of the five were differentiated from each other. For a closer examination of the systematic problems outlined above, we analyzed fifteen loci in six other Gammaridae, in addition to those of Siegismund et al. (1985).

Here we examine the phylogenetic relationships among twelve species in three genera of Gammaridae from north-western Europe. Two species are freshwater forms, G. pulex and Gammarus lacustris G. O. Sars, 1863. One species, $G$. duebenii, may live in fresh and brackish water environments, while the remaining nine are confined to brackish or marine waters, viz., Gammarus finmarchicus Dahl, 1938, G. zaddachi, G. salinus, G. oceanicus, Gammarus tigrinus Sexton, 1939, G. locusta, Chaetogammarus (Echinogammarus ?) marinus, Chaetogammarus (Echinogammarus ?) stoerensis (Reid, 1815) and Eulimnogammarus (Echinogammarus?) obtusatus (Dahl, 1938).

\section{MATERIAL AND METHODS}

The species used in the present study were collected during the summer of 1983. The collection locations are shown in fig. 1; for the species collected, locations, and dates of collection are as follows:

Gammarus tigrinus. - Breiholz in the Kiel Canal, Federal Republic of Germany, August 29. The animals were scraped off from piles at the ferry berth. Gammarus finmarchicus. - Northern shore of the island Tromlingen, north-east of the city Arendal, Norway, June 1. The animals were picked after turning over boulders.

Eulimnogammarus obtusatus. - Marine Biological Station at Espegrend, Norway, May 13. The animals were taken with a hand net after turning over stones in the Fucus belt on the shore, south of the harbour.

Chaetogammarus stoerensis. - Flaskebekk in the Oslofjord, Norway, a shore 150 


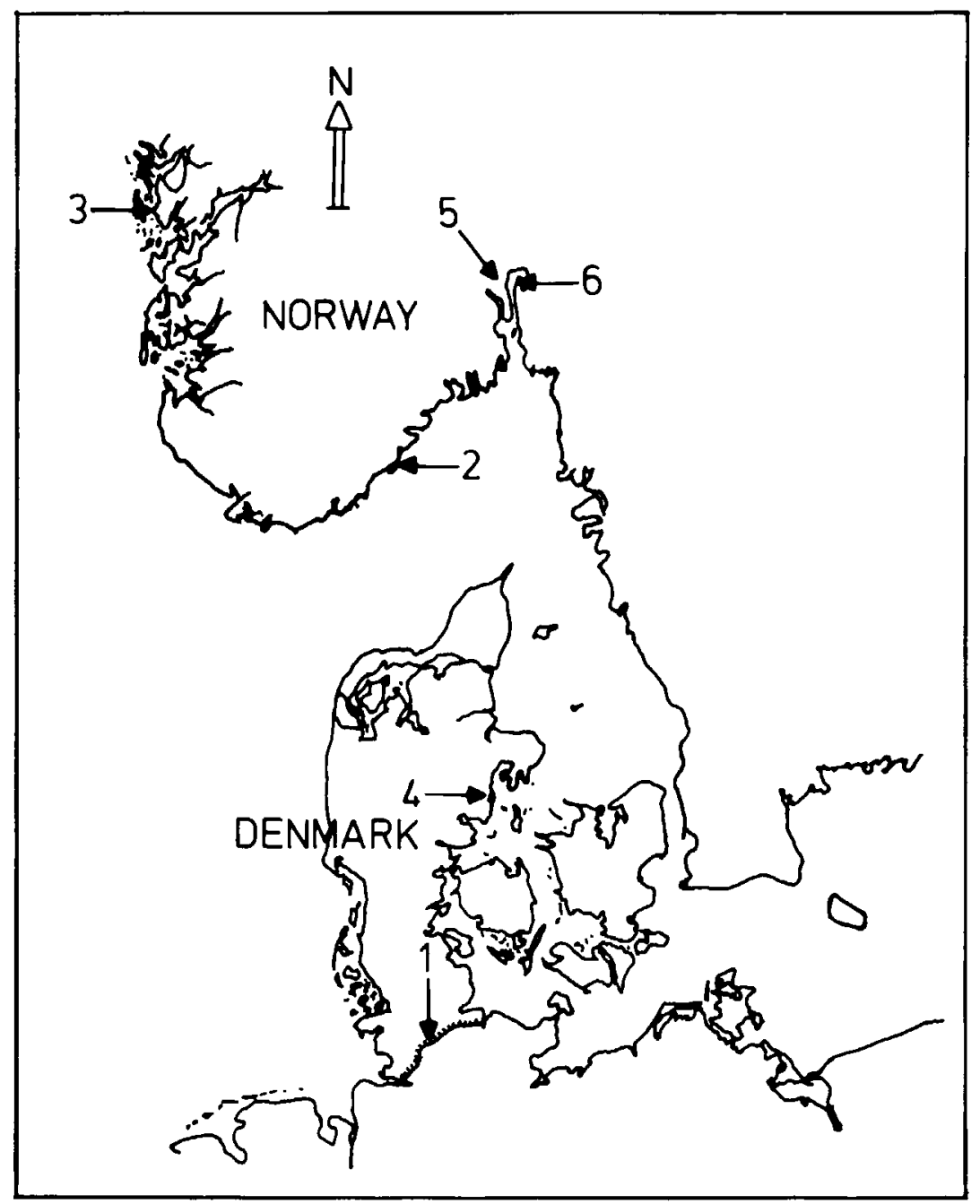

Fig. 1. Sampling locations for the species collected in addition to those of Siegismund et al. (1985). 1, Gammarus tigrinus Sexton, 1939; 2, Gammarus finmarchicus Dahl, 1938; 3, Eulimnogammarus obtusatus (Dahl, 1938); 4, Gammarus pulex (L., 1758); 5, Gammarus lacustris G. O. Sars, 1863;

6, Gammarus stoerensis (Reid, 1815). The names of the locations are given in the text.

$m$ north of the ferry berth, May 31. The animals were washed out from mussel clumps.

Gammarus pulex. - Kysing Fjord, Denmark, October 5. The animals were sampled with a kitchen sieve in a brooklet, midway between the Flynderhage point and the outlet of the river Odder $\AA$. The locality was about $10 \mathrm{~m}$ from the shoreline in a dense stand of Phragmites communis Trin.

Gammarus lacustris. - Southern shore of lake Padderudvannet, $5 \mathrm{~km}$ west of 
Asker, Norway, May 30. The animals were taken with a hand net moved through decaying vegetation in less than $1 \mathrm{~m}$ depth.

The amphipods were identified according to the keys of Vader (1972) and Lincoln (1979).

Electrophoresis. - The genetic variation at eighteen enzyme loci was analyzed by horizontal starch gel electrophoresis, see Siegismund et al. (1985) for a detailed description of the methods employed. For each of the six species mentioned above at least thirty specimens were analyzed for each enzyme with four C. marinus placed as controls on each gel. For each enzyme one gel was also run with a mixture of three specimens of all twelve species. In this comparison among species, specimens from the following Danish populations treated in Siegismund et al. (1985) were included: Chaetogammarus marinus at Fornæs, Gammarus duebenii, G. zaddachi, G. salinus, G. oceanicus and G. locusta from the Limfjord. A detailed description of these cites are given in Siegismund et al. (1985).

The following enzymes were analysed: ACP - Acid phosphatase, E.C. No. 3.1.3.2.; ADA - Adenosine deaminase, E.C. No. 3.5.4.4.; ALP - Alkaline phosphatase, E.C. No. 3.1.3.1.; APK - Argininephosphate kinase, E.C. No. 2.7.3.3.; DIA - Diaphorase, E.C. No. 1.6.2.2.; ES - Esterase, E.C. No. 3.1.1.1.; GOT - Glutamic-oxaloacetic transaminase, E.C. No. 2.6.1.1.; GPI -Glucosephosphate isomerase, E.C. No. 5.3.1.11.; GPT - Glutamic-pyruvic transaminase, E.C. No. 2.6.1.2.; LAP - Leucine aminopeptidase, E.C. No. 3.4.1.1.; MDH - Malate dehydrogenase, E.C. No. 1.1.1.37.; ME - Malic enzyme, E.C. No. 1.1.1.40.; MPI - Mannosephosphate isomerase, E.C. No. 5.3.1.8.; PEP - Peptidase, E.C. No. 3.4.11/13.; PGM - Phosphoglucomutase, E.C. No. 2.7.5.1.

The mobility of allozymes was measured relatively to the most frequent allozyme of $C$. marinus. From the allele frequencies the average genetic identity among the species was calculated according to Nei (1972). The genetic identities among the species were calculated from the loci that had been scored in both species in all pairwise comparisons among species pairs. The genetic identities were used to construct a dendrogram using unweighted pair group arithmetric averages according to Sneath \& Sokal (1973).

\section{RESULTS}

Of the fifteen enzyme stains tried, three did not result in satisfactory staining (MDH, DIA, and PGM) and have therefore not been included in the present study. Three enzyme stains (ADA, GOT, and ME) resulted in two stained regions which is interpreted as the products of two loci coding for the same enzyme. The locus that code for these enzymes have been numbered AdaI, AdaII, 


\section{TABLE I}

Relative mobility of the enzymes that are coded by the monomorphic loci

\begin{tabular}{lcccccc}
\hline Locus & G. tigrinus & G. finmarchicus & E. obtusatus & G. pulex & G. lacustris & C. stoerensis \\
\hline AdaI & 100 & 100 & 102 & 97 & 100 & 97 \\
AdaII & 100 & 100 & 139 & 70 & 115 & - \\
Alp & 103 & 94 & 97 & 103 & 106 & 93 \\
Es & 109 & 109 & 110 & 99 & 104 & 110 \\
GotI & 102 & 100 & 74 & 102 & 119 & 83 \\
Lap & 96 & 93 & 99 & 97 & 97 & 99 \\
MeI & 90 & 86 & 115 & 86 & 89 & 112 \\
MeII & 107 & 88 & 92 & 100 & 46 & 105 \\
Pep & 107 & 100 & 100 & 117 & 136 & 100 \\
\hline
\end{tabular}

GotI, GotII, MeI and MeII. The locus that codes for the most anodically moving enzyme is numbered $I$. The total number of loci used for analysis in this report thus amounts to fifteen.

In Eulimnogammarus obtusatus the Apk locus was not included since only a very low number of individuals could be stained. Chaetogammarus stoerensis showed only a single zone for the ADA enzyme. This zone is interpreted as the product of the locus AdaI. The AdaII locus is thus missing in this species. A single species showed a duplicated locus: Gammarus finmarchicus had two Gpi loci. Due to the difficulty of assessing the homology of these loci to the Gpi locus of the other species, the Gpi loci of $G$. finmarchicus have been excluded. Nine loci are monomorphic in all species. The mobility values of the enzymes coded by these loci are presented in table I. In this case, the average sample size is thirty individuals. The allele frequencies at the loci that are polymorphic in at least one of the species are shown in table II.

The data in tables I and II have been used for calculating the genetic identities for all species pairs (table III), which contains the six species studied by Siegismund et al. (1985) plus the six species of the present report. All twelve species are compared, and a dendrogram indicating the relationships among the species is shown in fig. 2 .

The genetic identity among most species pairs is relatively low, which is reflected in branching points at low similarity levels in the dendrogram of fig. 2. There is no indication of a separation of the twelve species into the three genera Eulimnogammarus, Chaetogammarus, and Gammarus. The genetic identities between species in the genus Gammarus are as low as the genetic identities between species placed in different genera. For example, the two species in the genus Chaetogammarus, $C$. marinus and $C$. stoerensis, do not seem to stand closer to each other than they are to any of the other species: the genetic identity among them is only 0.07 .

The species in the genus Gammarus cannot be separated into a group of marine species and a group consisting of the two freshwater species $G$. pulex 
TABLE II

Allele frequencies at the polymorphic loci. $\mathrm{N}$ is the sample size

\begin{tabular}{|c|c|c|c|c|c|c|c|}
\hline & & G. tigrinus & G. finmarchicus & E. obtusatus & G. pulex & G. lacustris & C. stoerensis \\
\hline \multirow[t]{7}{*}{$4 c p$} & 307 & 0 & 0 & 0.18 & 0 & 0 & 0 \\
\hline & 300 & 0 & 1.00 & 0 & 0 & 0 & 0 \\
\hline & 281 & 0 & 0 & 0.82 & 1.00 & 0 & 0 \\
\hline & 223 & 0 & 0 & 0 & 0 & 1.00 & 0 \\
\hline & 155 & 1.00 & 0 & 0 & 0 & 0 & 0 \\
\hline & 75 & 0 & 0 & 0 & 0 & 0 & 1.00 \\
\hline & $\mathrm{N}$ & 30 & 30 & 30 & 30 & 28 & 30 \\
\hline \multirow[t]{4}{*}{$4 p k$} & 158 & 0 & 0 & & 0 & 0.35 & 0 \\
\hline & 140 & 1.00 & 0 & & 0 & 0.66 & 1.00 \\
\hline & 155 & 0 & 1.00 & & 1.00 & 0 & 0 \\
\hline & $\mathrm{N}$ & 30 & 18 & 0 & 28 & 29 & 18 \\
\hline \multirow[t]{7}{*}{ GotII } & 134 & 0 & 0 & 0.07 & 0 & 0.05 & 0 \\
\hline & 116 & 0 & 1.00 & 0 & 0 & 0.95 & 0 \\
\hline & 100 & 0 & 0 & 0.93 & 1.00 & 0 & 0 \\
\hline & 69 & 1.00 & 0 & 0 & 0 & 0 & 0 \\
\hline & 55 & 0 & 0 & 0 & 0 & 0 & 0.02 \\
\hline & 16 & 0 & 0 & 0 & 0 & 0 & 0.98 \\
\hline & $\mathrm{N}$ & 29 & 30 & 30 & 30 & 30 & 30 \\
\hline \multirow[t]{7}{*}{ Gpi } & 165 & 0 & & 0 & 1.00 & 0 & 0 \\
\hline & 150 & 0.53 & & 0 & 0 & 1.00 & 0 \\
\hline & 136 & 0.47 & & 0 & 0 & 0 & 0 \\
\hline & 119 & 0 & & 0.95 & 0 & 0 & 0 \\
\hline & 100 & 0 & & 0.05 & 0 & 0 & 0 \\
\hline & 68 & 0 & & 0 & 0 & 0 & 1.00 \\
\hline & $\mathrm{N}$ & 29 & 0 & 30 & 30 & 30 & 29 \\
\hline \multirow[t]{7}{*}{ Gpt } & 182 & 0 & 0 & 1.00 & 0 & 0.76 & 0 \\
\hline & 167 & 0.89 & 0 & 0 & 0 & 0 & 0 \\
\hline & 165 & 0 & 0 & 0 & 0.02 & 0 & 0 \\
\hline & 117 & 0 & 1.00 & 0 & 0 & 0 & 0 \\
\hline & 100 & 0.11 & 0 & 0 & 0.96 & 0.24 & 0 \\
\hline & 30 & 0 & 0 & 0 & 0.02 & 0 & 1.00 \\
\hline & $\mathrm{N}$ & 14 & 22 & 25 & 27 & 23 & 15 \\
\hline \multirow[t]{7}{*}{ Mpi } & 186 & 0 & 0 & 0 & 0 & 1.00 & 0 \\
\hline & 163 & 0 & 0 & 0 & 0.87 & 0 & 0 \\
\hline & 158 & 0 & 0 & 0 & 0.13 & 0 & 0 \\
\hline & 122 & 0.93 & 1.00 & 0 & 0 & 0 & 0 \\
\hline & 111 & 0.07 & 0 & 0 & 0 & 0 & 1.00 \\
\hline & 100 & 0 & 0 & 1.00 & 0 & 0 & 0 \\
\hline & $\mathrm{N}$ & 30 & 17 & 30 & 30 & 30 & 30 \\
\hline
\end{tabular}

and $G$. lacustris. These two species have a very low genetic identity to each other. The introduced American species Gammarus tigrinus has genetic identities relative to the other species, of the same order as the European species have to each other, and does thus not seem less related to them than they are to each other. 


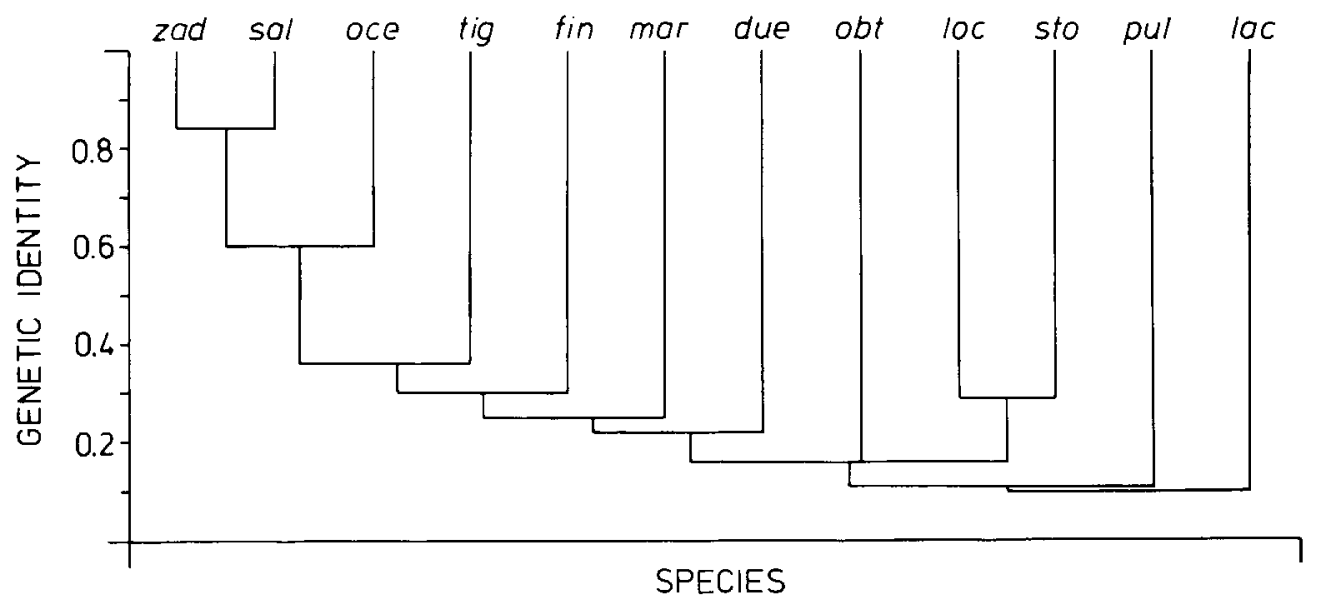

Fig. 2. Dendrogram based on the genetic identities of all species pairs (for further explanation, see text).

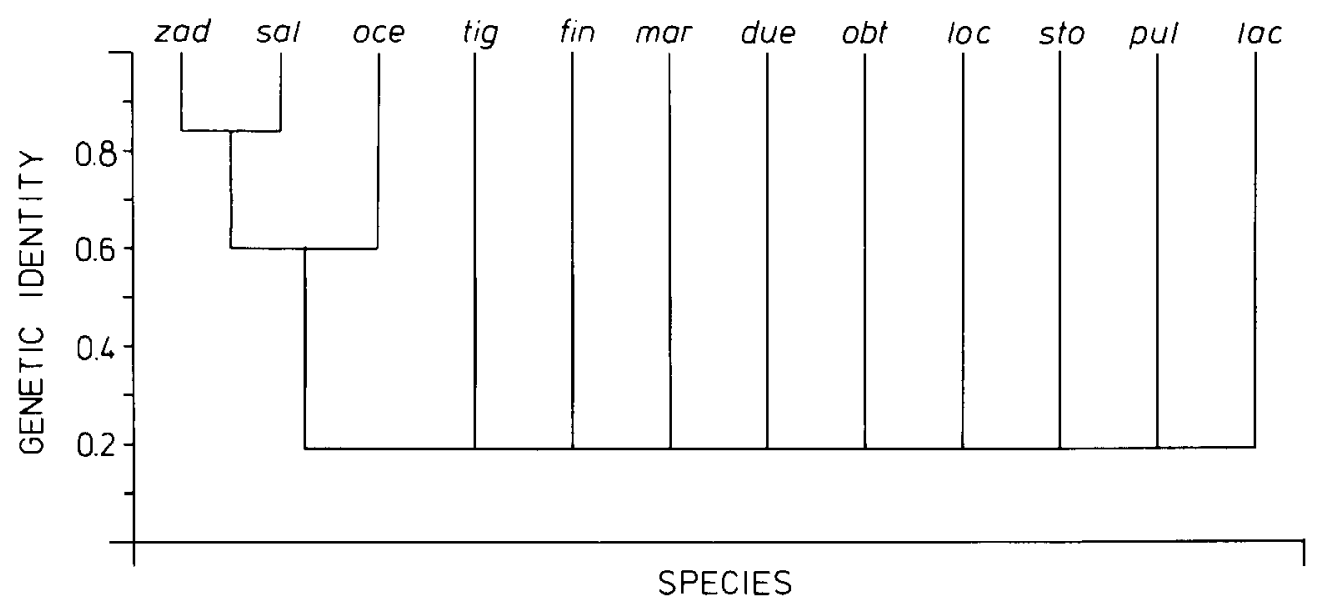

Fig. 3. An idcalised dendrogram showing the main relationships between the species (for further explanation, see text).

The only group that stands out is the Gammarus zaddachi-group, of which we have $G$. salinus and $G$. oceanicus in addition to $G$. zaddachi. Within this group, $G$. zaddachi and $G$. salinus are closest, with a genetic identity of 0.85 . They have about the same relationship to $G$. oceanicus, a genetic identity of 0.61 and 0.65 , respectively. The twelve species can thus be grouped into ten groups: the $G$. zaddachi-group and nine groups each consisting of a single species. This relationship among the species is illustrated in fig. 3, where the average genetic identity of 0.19 among all species comparisons has been used as a baseline. In- 
terpretations beyond that shown in fig. 3 are difficult, since such small identities are observed between the ten groups and only a moderate number of enzymes have been analyzed.

\section{DISCUSSION}

As expected from earlier protein studies of Gammaridae (see Introduction), our enzyme assay (table III) confirms that all twelve species are well defined according to the morphological criteria compiled in Karaman \& Pinkster (1977a) and Lincoln (1979). However, in the classification above species level we question several of the present arrangements.

The genetic identity between most species pairs is relatively low (table III). Within the genus Gammarus, genetic identities in species pairs are as low as those between Gammarus species and species in other genera: Chaetogammarus marinus, Chaetogammarus stoerensis, and Eulimnogammarus obtusatus. Further, a relationship between the two Chaetogammarus species is barely detected $(\mathrm{I}=0.07)$. Independently they show closer relationships to species placed in other genera (table III). Chaetogammarus is recognized as a part of the comprehensive genus Echinogammarus by Barnard \& Karaman (1980), and this group is mainly distributed in southern Europe and further south and eastwards (Stock, 1968, 1971, 1974). Unfortunately we lack Echinogammarus species in our analysis and may therefore, with reference to our data, only question the inclusion of Chaetogammarus into Echinogammarus. The low genetic relationship among $C$. marinus and $C$. stoerensis may perhaps weaken the status of Chaetogammarus as a separate genus. Future genetic studies of more southern and southeastern species are warranted in conjunction with the extensive morphological studies of Stock (see above).

Eulimnogammarus obtusatus is the only species in our study from this genus of mainly southern European and Lake Baikal amphipods (see Introduction). Eulimnogammarus obtusatus has its highest identity to $C$. stoerensis and nearly the same to $C$. marinus. This may indicate a connection to the Echinogammarusgroup (sensu Barnard \& Karaman, 1980), but judging from our data and the lack of other Eulimnogammarus species we may only question the position of $E$. obtusatus. Anyhow, the possibility that these three genera share some common ancestor(s) apart from Gammarus, should merit future attention.

Gammarus finmarchicus does not belong in the Marinogammarus/Chaetogammarus grouping (cf. table III and fig. 2). As for other species in this grouping our results contradict those of Holmes (1975), while we agree with Pinkster \& Stock (1970) in that $G$. finmarchicus at present should be kept in the genus Gammarus. Gammarus finmarchicus has a reduced inner ramus in uropod 3. Recall that Barnard \& Karaman (1980) regarded this morphological character as the only one separating their Echinogammarus from Gammarus. In this connection we may ask if perhaps the reduced inner ramus in uropod 3 in G. finmarchicus is a result 


\section{TABLE III}

Genetic identities among all species studied

\begin{tabular}{|c|c|c|c|c|c|c|c|c|c|c|c|c|}
\hline & $\begin{array}{l}\tilde{\Xi} \\
\tilde{\Xi} \\
\tilde{\Xi} \\
\tilde{\Xi} \\
0\end{array}$ & 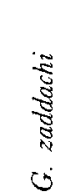 & 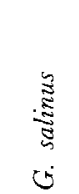 & 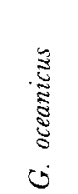 & 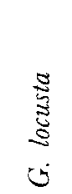 & 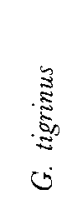 & 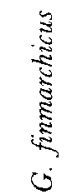 & 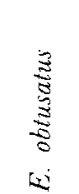 & 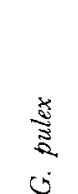 & 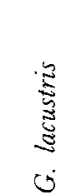 & 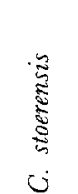 & 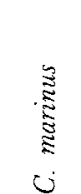 \\
\hline G. duebenii & - & 0.22 & 0.21 & 0.23 & 0.24 & 0.19 & 0.23 & 0.07 & 0.13 & 0.09 & 0.07 & 0.20 \\
\hline G. zaddachi & & - & 0.85 & 0.61 & 0.29 & 0.28 & 0.31 & 0.16 & 0.00 & 0.19 & 0.14 & 0.23 \\
\hline G. salinus & & & - & 0.65 & 0.19 & 0.38 & 0.24 & 0.09 & 0.00 & 0.21 & 0.08 & 0.18 \\
\hline G. oceanicus & & & & - & 0.23 & 0.38 & 0.34 & 0.10 & 0.00 & 0.14 & 0.15 & 0.28 \\
\hline G. locusta & & & & & - & 0.21 & 0.29 & 0.07 & 0.00 & 0.19 & 0.29 & 0.23 \\
\hline G. tigrinus & & & & & & - & 0.28 & 0.00 & 0.15 & 0.16 & 0.08 & 0.15 \\
\hline G. finmarchicus & & & & & & & - & 0.08 & 0.14 & 0.14 & 0.08 & 0.29 \\
\hline E. obtusatus & & & & & & & & - & 0.13 & 0.06 & 0.24 & 0.22 \\
\hline G. pulex & & & & & & & & & - & 0.09 & 0.07 & 0.20 \\
\hline G. lacustris & & & & & & & & & & - & 0.05 & 0.09 \\
\hline C. stoerensis & & & & & & & & & & & - & 0.07 \\
\hline C. marinus & & & & & & & & & & & & - \\
\hline
\end{tabular}

of convergent evolution, or should a genealogical relationship to Echinogammarus be seriously regarded?

Gammarus pulex and $G$. lacustris are widely separated $(I=0.09)$ and can by no means be placed in a group of freshwater species apart from the marine species. This supports Stock's (1969) rejection of Rivulogammarus.

Golikov \& Tzvetkova (1972) used the "ecological principle for evolutionary reconstruction" and suggested that $G$. locusta was the oldest existing species of Gammaridae sensu Lincoln (1979). They indicated that from an old G. locusta form their Marinogammarus line could have separated before a line producing Gammarus duebenii. In our investigation, G. zaddachi, G. salinus, and G. oceanicus form the only group of closely related species, and they are a part of the Lagunogammarus-group of Sket (1971). Golikov \& Tzvetkova (1972) recognized Lagunogammarus as the last group to separate from the $G$. locusta line. They believed $G$. oceanicus to be the oldest species in the $G$. zaddachi-group. Our results may support parts of their reconstruction, since the close relationship between $G$. salinus and $G$. zaddachi could suggest the most recent speciation event. A slightly higher genetic identity of $G$. salinus to $G$. oceanicus than in the pair $G$. zaddachi-G. oceanicus may indicate that $G$. zaddachi is the youngest species (table III), possibly separated from G. salinus as postulated by Golikov \& Tzvetkova (1972). The $G$. zaddachi-group may perhaps be placed in a separate genus Lagunogammarus, but until a study is undertaken on Gammarus wilkitzkii Birula, 1897 and Gammarus setosus Dementieva, 1931, we choose to follow Karaman (1975) and keep Lagunogammarus at subgeneric rank. 
The introduced American species G. tigrinus (Sexton, 1939) is at present expanding its distribution in Europe at the cost of the indigenous species, although some fluctuations occur (Pinkster \& Platvoet, 1983). Gammarus tigrinus has genetic identities relative to the other species of the same order as observed between the European species and does thus not seem less related to them than they are to each other. A possible tenuous connection of $G$. tigrinus to the $G$. zaddachi-group may deserve future attention. The position of $G$. tigrinus indicates that American and European Gammarus species should probably still be kept in the same genus as they are at present.

In conclusion, if we were to take a point of view solely based on the electrophoretic study, our suggestion would have been that the twelve species should be placed in the genus Gammarus, because of the low genetic identity between many species pairs, just as well within a genus as between genera. Or, alternatively, the ten groups (indicated in fig. 3) should have been taken to be ten genera, which is the most unrealistic alternative since several new genera would have to be erected. An exact evaluation of enzyme variations versus morphological variations is difficult, since there may be no linear correlation between these two parameters (White, 1980). However, we believe that genetic and morphological studies in combination may clarify taxonomic problems in general, and that this may represent a useful tool, especially in the analysis of convergence within Gammaridae.

\section{ACKNOWLEDGEMENTS}

We are indebted to the staff of the Institute of Ecology and Genetics who provided the working facilities. D. Andersen, F. B. Christiansen and V. Simonsen are acknowledged for help and comments during the work, as are J. L. Barnard, E. Bousfield and W. Vader for comments to an earlier draft of the manuscript. Parts of the chemical expenses and travelling costs were covered by a grant from the Norwegian Research Council (D.58.85-001), who also provided a grant to A.S. (D.51.41.47) during parts of the writing. The work was done while one of us (A.S.) was on a grant from the Nordic Council for Marine Biology.

\section{RÉSUMÉ}

Les relations phylogénétiques entre douze espèces d'Amphipodes de la famille des Gammaridae ont été étudiées par électrophorèse enzymatique et un minimum de quinze loci ont été pointés pour chaque espèce. L'épreuve enzymatique confirme que les douze espèces sont correctement décrites d'après les critères morphologiques. Les identités génétiques entre la plupart des paires d'espèces sont faibles, aussi bien qu'entre les genres, et il n'y a pas de claire indication d'une séparation entre Gammarus, Chaetogammarus et Echinogammarus, comme elles sont classées avec une interrogation dans Lincoln (1979). Seules les espèces Gammarus zaddachi, G. salinus et $G$. oceanicus forment un groupe séparé, mais ne sont pas transférées à Lagunogammarus et nous suggérons que Lagunogammarus soit encore conservé au rang de sous-genre. Gammarus tigrinus, qui a été introduit d'Amérique en Europe, n'est pas différencié des espèces européennes au point d'être placé dans un genre séparé. La position de Chaetogammarus et d'Eulimnogammarus est douteuse. Nous manquons malheureusement d'informations génétiques pour envisager un transfert 
de ces espèces au large genre Echinogammarus. Une séparation de la plupart des espèces entre Gammarus et Echinogammarus serait conforme à la littérature récente. Cependant, cette séparation est très discutable et nous avons trouvé que les paires d'espèces dans les différents genres (sensu Lincoln, 1979) avaient de plus fortes identités génétiques de l'une à l'autre, que les paires du même genre. Ceci montre bien les problèmes créés par la non-linéarité dans les relations entre les caractères génétiques et morphologiques et les possibilités d'évolution convergente dans ce groupe animal.

\section{REFERENCES}

Barnard, J. L. \& C. M. Barnard, 1983. Freshwater Amphipoda of the world. I. Evolutionary Patterns: i-xvii, 1-358 (Hayfield Associates, Mt Vernon, Virginia).

Barnard, J. L. \& G. S. Karaman, 1980. Classification of gammarid Amphipoda. Crustaceana, (suppl.) 6: 5-16.

BousfiELD, E. L., 1977. A new look at the systematics of gammaroidcan amphipods of the world. Crustaceana, (suppl.) 4: 282-316.

- - 1979a. A revised classification and phylogeny of amphipod crustaceans. Trans. R. Soc. Canada, 16: 343-390.

- - 1979b. The amphipod superfamily Gammaroidea in the northeastern Pacific region: systematics and distributional ecology. Bull. biol. Soc. Washington, 3: 297-357.

- - 1981. Evolution in North Pacific coastal marine amphipod crustaceans. In: G. SGUdder \& J. Reveri, (eds.), Evolution today. Second Int. Congr. Syst. Evol. Biol., Procecdings: $68-69$

- - 1983. An updated phyletic classification and palaeohistory of the Amphipoda. In: F. R. Schram, (ed.), Crustacean phylogeny: 257-277 (Balkema, Rotterdam).

Bulnheim, H.-P. \& A. Scholl, 1980. Evidence of genetic divergence between two brackishwater gammaridean sibling species. Mar. Ecol. Progr. Scr, 3: 163-165

- - 1981. Electrophoretic approach to the biochemical systematics of gammarids. Helgoländer Meeresunters., 34: 391-400.

Golikov, A. N. \& N. L. Tzvetkova, 1972. The ecological principle of evolutionary reconstruction as illustrated by marine animals. Mar. Biol., 14: 1-9.

Hessler, R. R., 1969. Peracarida. In: R. C. Moore, (ed.), Treatise on invertebrate palaeontology, Part R, Arthropoda, 4: R360-R393 (Geol. Soc. America, Inc., \& Univ. Kansas).

Hormes, J. M. C., 1975. A comparison of numerical taxonomic techniques using measurements on the genera Gammarus and Marinogammarus (Amphipoda). Biol. Journ. Linnean Soc. London, 7: 183-214.

Just, J., 1974. Palaeogammarus Zaddach 1864, with a description of a new species from western Baltic amber (Crustacea, Amphipoda, Crangonycidae). Steenstrupia, 3: 93-99.

Karaman, G. S., 1975. 69. Contribution to the knowledgc of Amphipoda. Revision of the Echinogammarus genera-complex. Archiv Biol. Nauka, Beograd, 27: 69-93.

- - 1977. The value of Neogammarus (Ruffo 1937) and its relation to the genus Echinogammarus Stebb. 1899 (fam. Gammaridae). Animalia, Catania, 4: 109-121.

Karaman, G. S. \& J. L. Barnard, 1979. Classificatory revisions in gammaridean Amphipoda (Crustacea), Part 1. Proc. biol. Soc. Washington, 92: 106-165.

Karaman, G. S. \& S. Pinkster, 1977a. Freshwater Gammarus from Europe, North Africa and adjacent regions of Asia (Crustacea, Amphipoda). Part I. Gammarus pulex-group and related species. Bijdr. Dierk., 47: 1-97.

- — \& - , 1977b. Freshwater Gammarus from Europe, North Africa and adjacent regions of Asia (Crustacea, Amphipoda). Part II. Gammarus roeseli-group and related species. Bijdr. Dierk., 47: 165-196.

Karaman, S., 1931. III. Beitrag zur Kenntnis der Amphipoden Jugoslaviens, sowie einiger Arten aus Griechenland. Prirod. Razprave, 1: 31-66.

Kolding, S. \& V. Simonsen, 1983. Phylogenetic relationships of five species of the amphipod genus Gammarus. Zool. Scripta, 12: 215-219.

Lilljeborg, W., 1852. Norges Crustaceer. Crustacea, a clariss. M.W. v. Dueben in Norwegia ad Christiansund et Bergen 1843-44 collecta. Öfers. K. VetenskAkad. Förh., 8 (1851): 19-25. 
- - 1855. Öfersikt af de inom Skandinavien hittils funna arterna af slägtet Gammarus Fabr. K. VetenskAkad. Handl., 1853: 443-460.

Lincoln, R. J., 1979. British marine Amphipoda: Gammaridae: i-vi, 1-658 (British Museum, London).

NeI, M., 1972. Genetic distance between populations. Amer. Natural., 106: 283-292.

Nyman, J. \& L. Westin, 1969. A contribution to the methods of classification for some Mysidae and Gammarus species in the Baltic. Rep. Inst. Freshwat. Res. Drottningholm, 49: $157-163$.

Orian, A. J. \& H. G. Callan, 1957. Chromosome numbers of gammarids. Journ. mar. biol. Ass. U.K., 36: 129-142.

Pinkster, S., 1973. On members of the presumed Baikal-genus Eulimnogammarus (Crustacea, Amphipoda) in western Europe. Verh. intern. Ver. Limnol., 18: 1498-1504.

Pinkster, S. \& D. Platvoet, 1983. Further observations on the distribution and biology of two alien amphipods, Gammarus tigrinus Sexton, 1939, and Crangonyx pseudogracilis Bousfield, 1958, in the Netherlands (Crustacea, Amphipoda). Bull. zool. Mus. Univ. Amsterdam, 9: 153-164.

Pinkster, S. \& J. H. Stock, 1970. Western European species of the presumed Baikal genus Eulimnogammarus (Crustacea-Amphipoda), with description of a new species from Spain. Bull. zool. Mus. Univ. Amsterdam, 1: 205-219.

Rathke, M. H., 1843. Beiträge zur Fauna Norwegens. Verhandl. kaiserl. LeopoldinischCarolinische Akad. Naturforscher Breslau, 20: 1-264.

Roux, A. L., 1967. Contribution à l'étude systématique des Gammares de groupe pulex (Crustacés Amphipodes): Application des methodes chromatographiques de dosage des acides aminés à des fins taxonomiques. Bull. biol. Fr. Belg., 101: 115-128.

SARS, G. O., 1863. Beretning om en i Sommeren 1862 foretagen zoologisk Reise i Christiania og Throndhjems Stifter. Nyt Mag. Naturvitensk, 12: 193-252.

Schellenberg, A., 1937. Schlüssel und Diagnosen der dem Süsswasser-Gammarus nahestehenden Einheiten ausschliesslich der Arten des Baikalsees und Australiens. Zool. Anz., 117: $267-280$.

Sexton, E. W., 1912. Some brackish-water Amphipoda from the mouths of the Weser and the Elbe, and from the Baltic. Proc. zool. Soc. London, 1912: 656-665.

Sexton, E. W. \& G. M. Spooner, 1940. An account of Marinogammarus (Schellenberg) gen. nov. (Amphipoda), with a description of a new species, M. pirloti. Journ. mar. biol. Ass. U.K., 24: 633-682.

Siegismund, H. R., V. Simonsen \& S. Kolding, 1985. Genetic studies of Gammarus. I. Genetic differentiation between local populations. Hereditas, 102: 1-13.

Sket, B., 1971. Zur Systematik und Phylogenie der Gammarini (Amphipoda). Bull. Sci., (A) $16: 6$.

Sneath, P. H. \& R. R. Sokal, 1973. Numerical taxonomy: i-xv, 1-573 (Freeman, San Francisco).

Stock, J. H., 1967. A revision of the European species of the Gammarus locusta-group (Crustacea, Amphipoda). Zool. Verh., Leiden, 90: 1-56.

- - 1968. A revision of the European species of the Echinogammarus pungens-group (Crustacea, Amphipoda). Beaufortia, 20: 13-78.

- , 1969a. Rivulogammarus, an amphipod name that must be rejected. Crustaceana, 17: $106-107$.

- - 1969b. Members of Baikal amphipod genera in European waters, with description of a new species, Eulimnogammarus macrocarpus from Spain. Proc. K. Ned. Akad. Wet., (C) 72: $66-75$.

- - 1971. A revision of the Sarathrogammarus-group (Crustacea, Amphipoda). Bijdr Dierk., 41: 94-121.

- - 1974. The systematics of certain Ponto-Caspian Gammaridae (Crustacea, Amphipoda). Mitt. Hamburg. zool. Mus. Inst., 70: 75-95.

VAder, W., 1972. Amfipode-slektene Gammarus og Marinogammarus i Norge, med en illustrert bestemmelsestabel til de Nordvest-europeiske arter: 1-23 (Mimeographed; Biologisk stasjon, N-5065 Blomsterdaien).

White, M. J. D., 1978. Modes of speciation: 1-455 (Freeman, San Francisco). 